\title{
Regional Aspects of Sectoral Digitalization: Problems and Prospects
}

\author{
Submitted 10/01/19, $1^{\text {st }}$ revision $12 / 02 / 19,2^{\text {nd }}$ revision $24 / 03 / 19$, accepted $05 / 04 / 19$
}

\author{
L.I. Popova ${ }^{1}$, I.D. Demina ${ }^{2}$, Y.S. Stepanenko ${ }^{3}$, \\ Q.N. $\operatorname{Tran}^{4}$, G.V. Meshkova ${ }^{5}$, M.A. Afonasova ${ }^{6}$
}

\begin{abstract}
:
Purpose: At present, high and sometimes record indicators have been achieved for the individual branches of agricultural production. Further intensive development of agriculture is due to the search for new ways to increase labor productivity and lower production costs which is the main aim of this research.

Design/Methodology/Approach: The methodological basis served as a systematic approach, which ensured comprehensiveness and purposefulness. Analytical, abstract-logical, economic-statistical, monographic and experimental research methods were also used in this work to examine problems and prospects of sectoral digitalization.

Findings: The agro-industrial complex demonstrates the growth of production indicators and is on the rise. The target indicators, laid down in the Food Security Doctrine, have already been achieved by many indices. To a large extent, it is due to a significant increase in the agro-industrial complex.

Practical implications: A proposed platform that would ensure a breakthrough in further technical modernization of production, can be created only if the technologies are improved based on their digitalization and orientation towards a specific consumer.

Originality/Value: The pin-point introduction of digital technologies in agricultural production confirms the high efficiency of the full innovative technical modernization. The proposed digital transformation of management in the agro-industrial complex of Russia is the value of this research with its originality compared to other ideas.
\end{abstract}

Keywords: Digital economy, modernization of agriculture, transformation, labor productivity, digitization of agriculture, regional specificity, food security.

JEL Classification: O14, O32, O38.

Paper type: Research article.

\footnotetext{
${ }^{I}$ Naberezhnye Chelny State Pedagogical University, Naberezhnye Chelny, Russia, e-mail: pli3008@mail.ru

${ }^{2}$ Financial University under the Government of the Russian Federation

${ }^{3}$ Irkutsk National Research Technical University, Irkutsk, Russian Federation

${ }^{4}$ Peoples' Friendship University of Russia (RUDN University), Moscow, Russia

${ }^{5}$ Bauman Moscow State Technical University, Moscow, Russia

${ }^{6}$ Tomsk State University of Control Systems and Radioelectronics, Tomsk, Russia
} 


\section{Introduction}

The share of the total product of agricultural enterprises in Russia's GDP is currently about $4.4 \%$ (in terms of rubles is about 4 trillion rubles). The share of people, employed in the industry out of the total number of workers in the country's economy is about $6.8 \%$ - this is 4.7 million people. Currently, 113 thousand IT specialists work in the agro-industrial complex - it is a disastrously small figure that needs to be increased at least by 10 times (Ushachev et al., 2017; 2018). The introduction of new technologies is the only option for the development of the agroindustrial complex of the country and will allow the enterprises of the industry to compete more successfully in the Russian and international markets, to increase biosafety, quality and attractiveness of work in the agro-industrial complex (Kopteva and Koptev, 2018a; Tananykhin and Saychenko, 2017).

Possessing potential in introducing land into circulation, Russia is increasing grain yield, showing the highest growth since 2000: yields increased by almost 60 percent. At the same time, in terms of a number of indicators, Russia lags far behind the leading economies (Korableva et al., 2018), grain yields are lower than those in the United States and Germany by 3-4 times, the cost of agricultural products per employee is 22 times lower than in the United States (Abdrakhmanova et al., 2017; Kozhokin \& Zherelina, 2017). Through the mechanisms of state support for agribusiness, within the available funding, almost 3-fold increase in the amount of funds for the purchase of agricultural equipment at discounted prices (up to 5.2 billion rubles.), Is re-sectors, however, weak export potential leads to a reduction of investment in fixed capital, savings on purchased and supplied equipment leads to the fact that it does not meet the requirements of connecting to the telemetry and control platforms of the Internet of things (Ushachev et al., 2018).

At the same time, Russia should be ready for domestic agricultural producers to enter the foreign market, especially with high value-added products. Agriculture in Russia is an integral part of the agro-industrial complex; the Digitalization of Agriculture program should provide participants with the opportunity to use broadband, mobile, LPWAN communications, information technologies (small and big data, AI, control platforms) of domestic instrument making (tags, controllers, sensors, controls) (Maslova et al., 2017; Polyakova et al., 2019).

\section{Methodology}

The theoretical and methodological basis of the study are the works of domestic and foreign scientists on the problems of agricultural production based on the introduction of advanced digital technologies; issues of increasing labor productivity in agriculture; research and recommendations of the Russian Academy of Agricultural Sciences, laws of the Russian Federation, decrees of the President and decrees of the Government of the Russian Federation, regulatory acts of the subjects of the Federation. The source materials were the materials of the Federal Register of 
Russian Federation, the data of the Federal State Statistics Service of the Russian Federation, the Ministry of Agriculture of the Russian Federation, materials of authoring, technical and reference literature. The methodological basis served as a systematic approach, which ensured comprehensiveness and purposefulness. Analytical, abstract-logical, economic-statistical, monographic and experimental research methods were also used in the work.

\section{Results}

Opportunities to modernize the industry are enormous (Lavrenko and Korolev, 2018; Nefedov, 2018; Nefedov and Klepikov, 2018; Prischepa and Averyanova, 2017; Tarman, 2017; Bittman et al, 2017; Tananykhin et al., 2018; Shagiakhmetov et al., 2018; Ovcharenko et al., 2017; Vasiliev and Mardashov, 2017).

The country's food security and the development of export potential are turning agriculture into a high-tech industry that can not only provide themselves with food, but also many countries around the world, and also create opportunities for introducing new innovative developments that did not exist before, stimulate management decisions that can provide people with high-quality and safe products (Movchan and Yakovleva, 2014; Kuznetsov, 2017; Koptev and Kopteva, 2017; Lavrenko et al., 2019; Koptev and Kopteva, 2018b; Sozinova et al., 2017; Polyakova et al., 2018). The diagrams presented below allow you to visually evaluate some aspects of digitalization in the Russian agro-industrial complex (Figures 1 and 2).

\section{Figure 1. Optimization of the cost of agricultural production}

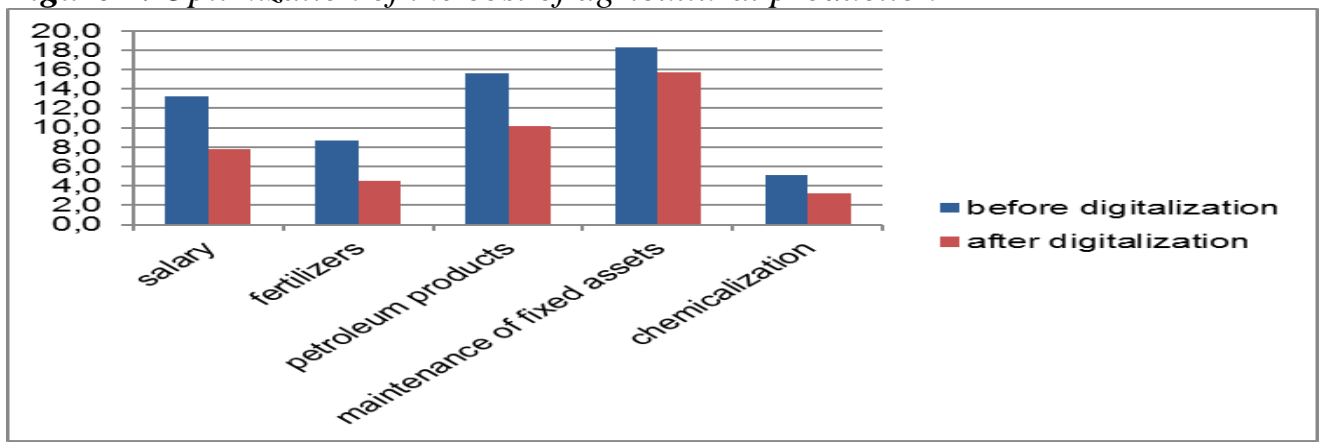

According to experts, during the season, the farmer must make more than 40 different solutions within a limited period. Many of these solutions are subject to digitalization (Prischepa and Chumakova, 2016; Podoprigora and Saychenko, 2017; Podoprigora et al., 2016; Prischepa et al., 2016; Podoprigora and Raupov, 2018; Gurman et al., 2017). The current level of digitalization of domestic agriculture raises serious concerns: the lack of scientific and practical knowledge of innovative modern agricultural technologies and methodologies, the lack of a global forecast for 
agricultural prices, and the underdeveloped logistics, storage and delivery systems lead to high production costs.

Figure 2. Structure acquired by organizations of new technologies and software products, units

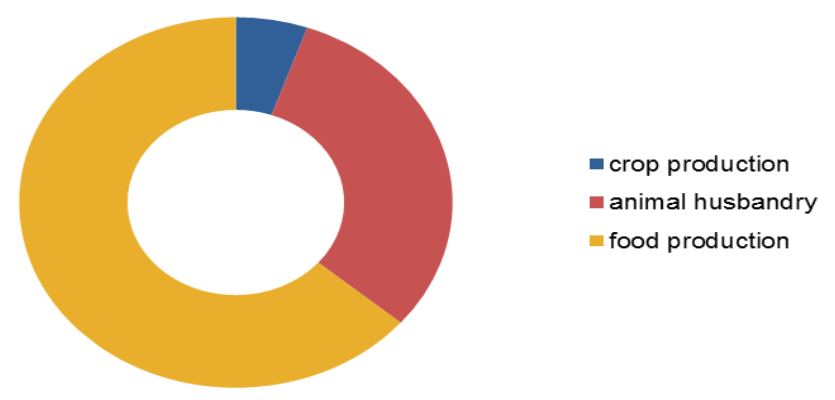

A small number of agricultural producers have the financial capacity to purchase new equipment, use of IT equipment and platforms (Prischepa et al., 2018a; Korchevenkov and Aleksandrova, 2018; Nikolaeva et al., 2018; Prischepa et al., 2018b; Sultanova and Mardashov, 2016; Korobov and Podoprigora, 2018; Prischepa et al., 2018c). According to Rosstat, in 2015 ICT expenditures in the section "Agriculture, hunting and forestry" amounted to 4 billion rubles, which is 0.34 percent of all ICT investments in all sectors of the economy, in 20170.85 billion rubles or 0.2 percent.

This is the lowest indicator by industry, which indicates a low digitalization of the domestic agricultural economy, but this figure emphasizes that the industry has the greatest potential for investment in ICT technology (Abdrakhmanova et al., 2017; Korobov and Raupov, 2017; Aleksandrova and Talovina, 2017; Ushachev et al., 2018; Yamova et al., 2018; Tananykhin and Shagiakhmetov, 2016; Prokhorova et al., 2016; Sharifov and Mardashov, 2018; Safieva et al., 2017; Aleksandrova et al., 2017; Podoprigora and Korobov, 2017; Raupov and Podoprigora, 2017; Raupov and Korobov, 2018; Kayumova et al., 2019; Aleksandrova et al., 2019).

The transformation of agriculture in the Russian Federation includes the digitization of the following areas of production: crop production, primary processing, accelerated selection and genetics, vegetables of open and closed ground, greenhouse industry, fruits and berries, processing and storage technologies, aquaculture, fish farming, processing technologies, poultry and livestock, nutrition, accelerated selection and genetics. As part of the industry transformation measures, at the first stage (2018-2021), it is necessary to pilot methods for stimulating the introduction of digital technologies by agricultural producers, collecting and analyzing objective data from market participants (Magsumov, 2018; Achaeva et al., 2018), reintegrating and enriching the data necessary for digital farming from government sources. 
The directions that will be directly influenced by the transformation of agriculture are presented in the diagram (Figure 3).

Figure 3. Effects of sectoral transformation

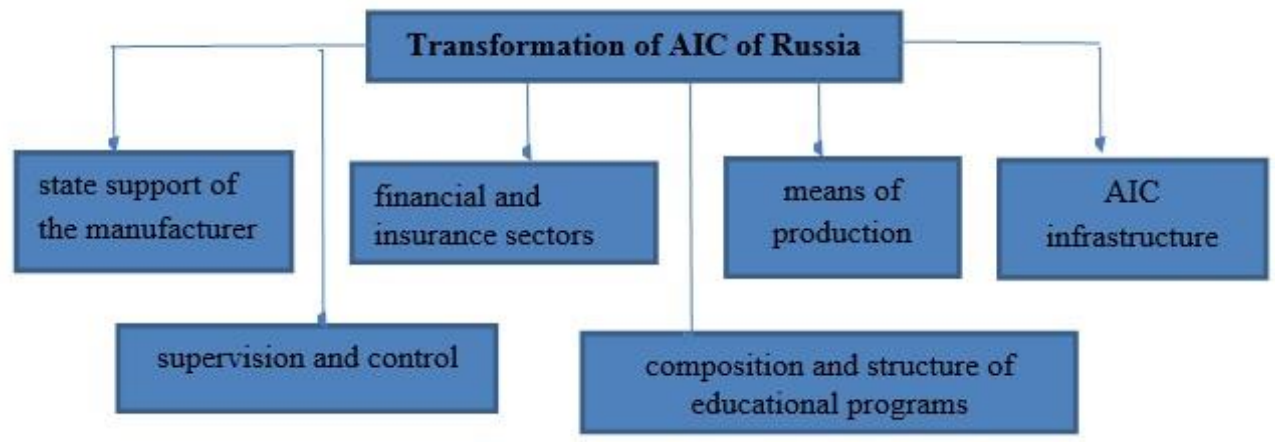

Piloting takes place on a prototype of a public-private platform "digital agriculture" with the participation of the information system of the Analytical Center of the Ministry of Agriculture of the Russian Federation. At the first stage, the participants of the program, together with the Ministry of Agriculture of the Russian Federation, form and ensure the process of determining dynamic seasonal KPIs by sector of agriculture (Abdrakhmanova et al., 2017; Poltarykhin et al., 2018a; Poltarykhin et al., 2018b; Voronkova et al., 2018).

The second stage (2019-2024) will affect, in our opinion, large and medium agricultural production. The approved technologies will be scaled up by business entities, including using incentive measures, by shifting state support in favor of enterprises introducing digitalization processes and technologies using objective production control methods. This will allow farmers to integrate into the global space using world standards of compliance with the requirements of quality and traceability of products (Solnyshkina and Ismagilova, 2015; Amurskaya and Solnyshkina, 2015; Solnyshkina, 2016). A digital social service platform based on PPP (Public private partnership) principles is being formed. Technological and organizational bases for distance learning and advanced training of workers in the agro-industrial complex with access to the most advanced technologies in the field of agriculture and product processing are being formed and launched. Assistance is provided to scientific institutions of the Russian Federation working in the agricultural sector in launching a system of scientific advice, manufacturers of technologies for growing crops, animals and processing products.

At the third stage (2022- ...), an end-to-end information support system in the field of agriculture should be created, all agricultural production cycles will be digitized, which will reduce costs and increase product availability, including by minimizing the participation of intermediaries in the marketing chains. There will be digital fragmentation (division of labor) and "uberization" of farms (for example, the owner 
of cattle and dairy production is responsible only for feeding, walking and milking, the supply of feed, drugs, slaughter, export of products carried out by specialized companies).

The Altai Territory, being one of the largest agrarian regions, makes a worthy contribution to the achievements of the industry and the solution of the problem of ensuring the country's food security for a variety of food products. According to the Ministry of Agriculture of the Altai Territory, agriculture plays a significant role in the socio-economic development of the region, forming $20 \%$ of the gross regional product. Almost $70 \%$ of the territory falls on agricultural land (11.5 million hectares), while the arable land area - more than 6.5 million hectares - is the largest in the Russian Federation. More than $43 \%$ of the population of the region live in rural areas. Due to the course of modernization and intensification of the agricultural sector, the Altai Territory firmly holds the leading position in the country in the production of main types of agricultural products and foodstuffs. More than $80 \%$ of production is exported annually from the region, the task of increasing exports is being successfully solved.

\section{Discussion}

At the regional level, according to the Ministry of Agriculture of the Altai Territory, in 2015, the Regional Information System IS.RESPAK was introduced, designed to comprehensively automate the process of bringing state support funds based on personal accounts of agricultural producers of the region, as well as managing the industry based analysis of the industry in the region as a whole. The solution is based on open technologies, which corresponds to the program of import substitution and does not require the purchase of licenses by the number of jobs. In 2015, this decision became the winner of the 3rd All-Russian competition of regional and municipal informatization projects PROF-IT, received a positive assessment of a large number of experts and has already been implemented in six regions of the Russian Federation (Novosibirsk, Irkutsk regions, Krasnoyarsk Krai, Khanty-Mansi Autonomous District, Republic of Altai and Komi).

Studies show that the entire volume of state support for agricultural producers of the Altai Territory is processed by this system. In 2018, the system processed over 12.5 thousand applications for state support, totaling more than 3.3 billion rubles. With the help of the IS.RESPAK system, 42 thousand reports of agricultural producers were received and processed. Our analysis shows that at the present time in agriculture of the Altai Territory advanced digital technologies cover more than 660 thousand hectares of arable land, which is approximately $10 \%$ of its total area. Space monitoring of fields, remotely controlled tractors and harvesters, precision farming systems are not prospects for the distant future, but already today for the agricultural complex of the region. For example, in the Rodinsky farm (part of the KDV-Group), using a wide range of IT solutions (satellite navigation equipment, elements of precision farming, own weather stations) over an area of over 15 thousand hectares, 
the yield of a number of crops increased threefold. Consumption of fuels and lubricants due to the installation of special sensors (satellite navigation) is reduced by $25-30 \%$.

At the agricultural enterprise "Agrofirm Harvest" (Zonal District) due to the introduction of individual elements of the "figures" on an area of more than 8 thousand hectares over the last five years, the yield of winter crops increased by $25 \%$ and exceeded 54 centners per hectare last year. The farm "Partner" (Mikhailovsky District) relies on the "smart" agricultural equipment and in the production uses the latest achievements of the world agricultural engineering. On the fields of the farm, on the area of more than 22 thousand hectares, modern sowing complexes, sprayers with photovoltaic cells, as well as the differentiated application of mineral fertilizers, the latest models of harvesting equipment are working (Kochneva et al., 2019).

At the agricultural enterprise "Plemreproduktor Timiryazevsky" (Mamontovsky District), crop yields are raised with the help of a liquidizer - an injector of liquid mineral fertilizers. The application is carried out according to the track of the movement of the vehicle built by the satellite navigation system, the application of fertilizers is carried out to the desired depth. Thus, it was revealed that there are many farms that use elements of digital technologies in the region, but the degree of equipment is different for everyone. If we talk about satellite navigation systems, then its coverage is large, almost all large agricultural enterprises have such monitoring systems. Individual elements of precision farming are being developed and introduced in more than 100 farms. The total use of precision farming systems is carried out in 15 enterprises. Unmanned aerial vehicles operate in the fields of about 10 farms. In addition, several enterprises receive such services on a contractual basis.

Studies show that the growing demand for high technology in agriculture stimulates agricultural machinery enterprises in the Altai Territory to create competitive domestic machines (Aleksandrova and Afanasova, 2019). High-tech innovative equipment for precision farming is developed and implemented by the Barnaul special design bureau "Vostok", the company "Era of New Technologies". This direction is a priority for the Altai cluster of agricultural engineering, which includes about 30 organizations - agricultural machinery enterprises, educational and research institutions, and public organizations. The process of digitalization in the region is hampered by technical problems. In some areas, the data transfer rate still bears the status of "unstable". In the fields, there is often no mobile connection at all. In such conditions, digital data obtained from sensors on the equipment is accumulated, but it can be quickly transferred only in the zone of stable coverage. And then what is the use of them? There are questions about the accuracy of positioning. Available technical capabilities allow you to track agricultural equipment in the fields with an accuracy of 10-15 meters. This is clearly not enough for accurate seeding. In this case, the error should not exceed 1,5-2 centimeters. 
This problem is planned to be solved in 2019. It is assumed that the "Russian space systems" can create a network of basic reference stations of high-precision agriculture in the Altai Krai. The company plans to install five similar stations in three districts with the most developed agricultural production. If the project is successful, it will be expanded to the scale of the entire region. According to experts, this will require about 60 million rubles. We have determined that in order to successfully achieve the goals set in the region, three tasks will be required: development of infrastructure, training, as well as the provision of modern technology that can use digital technology. This year the Ministry of Agriculture of the Altai Territory is launching a pilot project on digital transformation of agriculture in the region, including the creation of an appropriate center of competence.

\section{Conclusion}

The pilot project on the digitization of agriculture in the Altai Krai is aimed at implementing the main directions of the departmental federal project "Digital Agriculture", elaborated by the Ministry of Agriculture of the Russian Federation, the provisions and components of which are supported by the authors. However, due to the regional specifics, the expediency of introducing a centralized "federal intellectual system of state support measures + personal account of the recipient of a grant" causes doubt. For example, the procedure for providing types of the state support in the regions is different - it is associated with the agrarian specialization of the territories. In some regions, animal husbandry is actively developed, while crop production is developed in other regions, or some areas have better climatic conditions for the cultivation of sugar beet, other areas - for the cultivation of corn, buckwheat, and lentils. Based on this, the regional authorities determine the directions that need to be supported. Everywhere, there is and there will be regional specificity, therefore it is impossible to create unified features of smart contracts.

It is proposed to create a distributed information system with regional segments, integrated with the central federal part. This will provide a complete picture of what is happening in the industry in the country without losing flexibility and speed of making changes in the types of support, as well as ensure a high level of reliability. The system of the authors is exactly such a solution. The results of implementing the pilot project in the Altai Krai can be the basis for building a digitalization platform for agriculture at the federal level. On the one hand, being a pilot region is a big responsibility, on the other one - it is an opportunity to test and implement the best digital solutions, available in the country and the world. This work will expand the range of provided digital services, increase the yield of ecologically clean agricultural products, increase the level of consumption of functional food products, and thus improve the quality of life of the population. 


\section{References:}

Abdrakhmanova G.I., Gokhberg L.M., Kevesh M.A. 2017. Indicators of the digital economy: 2017: Statistical compilation. National researche University "Higher School of Economics". M.: HSE, 320 p.

Achaeva, M., Daurova, A., Pospelova, N. \& Borysov, V. 2018. Intercultural education in the system of training future teachers. Journal of Social Studies Education Research, 9(3), 261-281, doi:10.17499/jsser.48690.

Amurskaya, O.Y. \& Solnyshkina, M.I. 2015. Photo-sharing communities' discourse: Strategies and language. Journal of Language and Literature, 6(2), 93-100, doi:10.7813/j11.2015/6-2/18.

Aleksandrova, T., Romanenko, S. \& Arastumian, K. 2017. Electrochemistry research of preparation slurry before intermediate flotation for sulphide-polimetallic ores. Paper presented at the International Multidisciplinary Scientific GeoConference Surveying Geology and Mining Ecology Management, SGEM, 17(11), 841-848, doi:10.5593/sgem2017/11/S04.107.

Aleksandrova, T.N. \& Talovina, I.V. 2017. Platinum-group metals in residual soils and potential efficiency of their processing in gravity concentrators. Journal of Mining Science, 53(3), 553-558, doi:10.1134/S106273911703250X.

Aleksandrova, T., Romanenko, S. \& Arustamian, K. 2019. Research of slurry preparation before selective flotation for sulphide-polymetallic ores. Paper presented at the IMPC 2018 - 29th International Mineral Processing Congress, 2071-2078.

Aleksandrova, T.N. \& Afanasova, A.V. 2019. Fine-dispersed particles of noble metals in sulphide carbonaceous ores and its beneficiation prospects. Paper presented at the IMPC 2018 - 29th International Mineral Processing Congress, 2368-2376.

Bittman, B., Davies, A., Russell, W. \& Goussakova, E. 2017. Advance Placement and the Achievement Gap in the 21st Century: A Multiple Linear Regression of Marginalized Populations in AP Enrollment. Research in Social Sciences and Technology, 2(2). Retrieved from http://ressat.org/index.php/ressat/article/view/46

Gurman, M.A., Aleksandrova, T.N. \& Shcherbak, L.I. 2017. Flotation of low-grade goldand carbon-bearing ore. Gornyi Zhurnal, (2), 70-74, doi:10.17580/gzh.2017.02.13.

Implementing UN/CEFACT e-Business standards in Agricultural Trade: Official Website of United Nations Economic Commission for Europe: https://www.unece.org.

Kayumova, G., Sheymardanov, S., Akhtarieva, R. \& Zhundibayeva, A. 2019. Developing creative potential of a schoolchild by means of native language. Journal of Social Studies Education Research, 10(1), 81-92.

Kochneva, O.E., Nefedov, U.V. \& Fedorov, N.V. 2019. Establishing the correlation between reservoir properties and facies features of the bashkir sediments of the gagarinskoye field. Neftyanoe Khozyaystvo - Oil Industry, (2), 24-27, doi:10.24887/0028-24482019-2-24-27.

Kopteva, A.V. \& Koptev, V.Y. 2018a. Automatic measuring system for oil stream paraffin deposits parameters. Paper presented at the IOP Conference Series: Materials Science and Engineering, 327(4), doi:10.1088/1757-899X/327/4/042053.

Koptev, V.Y. \& Kopteva, A.V. 2018b. Improving pit vehicle ecology safety. Paper presented at the Journal of Physics: Conference Series, 1015(5) 16DUMMY, doi:10.1088/1742-6596/1015/5/052014.

Koptev, V.Y. \& Kopteva, A.V. 2017. Developing an ecological passport for an open-pit dump truck to reduce negative effect on environment. Paper presented at the IOP Conference Series: Earth and Environmental Science, 66(1), doi:10.1088/1755- 
$1315 / 66 / 1 / 012009$.

Korableva, O.N., Kalimullina, O.V., Zaytseva, A.A. \& Larionov, A.I. 2018. Elaboration of database for the subject domain of innovation and economic growth potential. Paper presented at the Proceedings of the 31st International Business Information Management Association Conference, IBIMA 2018, Innovation Management and Education Excellence through Vision 2020, 6065-6073.

Korchevenkov, S. \& Aleksandrova, T. 2018. Investigation of the influence a morphologic characteristic of the noble metal particles on gravity efficiency devices. Paper presented at the International Multidisciplinary Scientific GeoConference Surveying Geology and Mining Ecology Management, SGEM, 18(1.4), 99-104, doi:10.5593/sgem2018/1.4/S04.013.

Korobov, G. \& Raupov, I. 2017. Study of adsorption and desorption of asphaltene sediments inhibitor in the bottomhole formation zone. International Journal of Applied Engineering Research, 12(2), 267-272.

Korobov, G. \& Podoprigora, D. 2018. Depth computation for the onset of organic sedimentation formation in the oil producing well as exemplified by the sibirskoye oil field. Acta Technica CSAV (Ceskoslovensk Akademie Ved), 63(3), 481-492.

Kozhokin, E.M. \& Zherelina, O.N. 2017. The nation at the change of epochs. Russian state and society at the turn of the XX century. Giornale di Storia Costituzionale, 33(1), 67-80.

Kuznetsov, V.S., Suprun, I.K. \& Petrov, D.S. 2017. Assessment and reduction of drilling waste impact on the environment components. Neftyanoe Khozyaystvo - Oil Industry, (1), 94-95.

Lavrenko, S.A., Korolev, I.A. 2018. Analysis of Cambrian clay cutting during SaintPetersburg subway construction. Gornyi Zhurnal (2), 53-58.

Lavrenko, S.A., Shishljannikov, D.I., Maksimov, A.B. 2019. Energy efficient unit executive body for tunneling and cleaning operations. Innovation-Based Development of the Mineral Resources Sector: Challenges and Prospects - 11th conference of the Russian-German Raw Materials, 287-292.

Magsumov, T.A. 2018. Vocational school and studying youth in the Russian revolution of 1905. Terra Sebus, 10, 289-313.

Maslova V.V., Borkhunov N.A., Zaruk N.F. 2017. Economic regulation of reproduction in the AIC AIC: Economics and Management, № 4, 51-60.

Maslova V.V., Zaruk N.F., Avdeev M.V. 2017. Production and competitiveness of grain and its processing products in the EAEU Member States. Economics of agricultural and processing enterprises, № 9, 19-24.

Maslova V.V., Zaruk N.F., Avdeev M.V. 2018. Factor analysis of the competitiveness of agri-food products in the EAEU Member States. AIC: Economics and Management. № 4, 75-85.

Movchan, I.B., Yakovleva, A.A. 2014. The way of structural interpretation of potential fields under condition of a priori geological information minimum. Biosciences Biotechnology Research Asia.

National Technology Initiative: Agency for Strategic Initiatives. https://asi.ru/nti.

Nefedov, Y. 2018. The arctic shelf and hard to recover oil reserves as alternative development of russian resource base. Paper presented at the Saint Petersburg Conference: Innovations in Geosciences.

Nefedov, Y.V. \& Klepikov, I.V. 2018. Occurrence regularities of nitrogen defects in the ural type crystal diamonds from different regions, doi:10.4028/www.scientific.net/KEM.769.201. 
Nikolaeva, N.V., Aleksandrova, T.N. \& Elbendari, A.M. 2018. Ore strength property evaluation in the design of ore preparation cycles. Paper presented at the Geomechanics and Geodynamics of Rock Masses, 1, 333-338.

Ovcharenko, Y.V., Gumerov, R.R., Bazyrov, I.S., Kunakova, A.M., Mardashov, D.V., Gunkin, A.S. \& Legkokonets, V.A. 2017. Well killing specifics in conditions of fractured and porous carbonate reservoirs of the eastern part of the orenburgskoye oil-gas-condensate field. Neftyanoe Khozyaystvo - Oil Industry, (12), 52-55.

Podoprigora, D. \& Korobov, G. 2017. Selection of the acidizing compositions for use in terrigenous reservoirs with high carbonate content. International Journal of Applied Engineering Research, 12(2), 249-255.

Podoprigora, D. \& Raupov, I. 2018. Research of the influence of polymeric drilling mud on the filtration-capacitive properties of polymictic sandstones. Acta Technica CSAV (Ceskoslovensk Akademie Ved), 63(4), 537-546.

Podoprigora, D. \& Saychenko, L. 2017. Development of acid composition for bottom-hole formation zone treatment at high reservoir temperatures. Espacios, 38(48).

Podoprigora, D.G., Shangaraeva, L.A., Usenkov, A.V. \& Ilyushin, P.Y. 2016. Development of acid composition for bottom-hole formation zone treatment at high reservoir temperatures. Neftyanoe Khozyaystvo - Oil Industry, (4), 122-124.

Poltarykhin, A.L., Suray, N.M., Zemskov, Y.V., Abramov, Y.V. \& Glotko, A.V. 2018 a. Food safety in the russian federation, its problems with the solutions. Academy of Strategic Management Journal, 17(4).

Poltarykhin, A.L., Alekseev, A.E., Kudryavtsev, V.V., Makhanova, T.A., Voronkova, O.Y. \& Aydinov, H.T. 2018b. Prospects for the development of the green economy of russian federation. European Research Studies Journal, 21(4), 470-479.

Polyakova, A.G., Akhmetshin, E.M., Goloshchapova, L.V., Rakhmeeva, I.I., Noeva, E.E. \& Rakovskiy, V.I. 2018. A model of regional economic space modernization. European Research Studies Journal, 21, (Special Issue 2), 624-634.

Polyakova, A.G., Loginov, M.P., Serebrennikova, A.I. \& Thalassinos, E.I. 2019. Design of a socio-economic processes monitoring system based on network analysis and big data. International Journal of Economics and Business Administration, 7(1), 130139.

Prischepa, O.M. \& Chumakova, O.V. 2016. Petroleum potential of marginal parts of the timan-pechora sedimentary basin. Paper presented at the 7th EAGE Saint Petersburg International Conference and Exhibition: Understanding the Harmony of the Earth's Resources through Integration of Geosciences, 399-403.

Prischepa, O.M., Chumakova, O.V., Grokhotov, E.I., Makarova, I.R. \& Averyanova, O.Y. 2016. Approaches to hydrocarbon evaluation in low porous shale strata based on domanik deposits study (timan-pechora province). Paper presented at the Geomodel 2016 - 18th Science and Applied Research Conference on Oil and Gas Geological Exploration and Development.

Prischepa, O., Bogatsky, V., Chumakova, O., Shaburova, M. \& Kuranov, A. 2018a. Improving of geological petroleum zoning of the northern timan-pechora province. Paper presented at the Saint Petersburg Conference: Innovations in Geosciences.

Prischepa, O., Chumakova, O., Zemlyakov, A., Orlova, L. \& Blinkova, E. 2018b. Assessment of petroleum exploration activity performed in the timan-pechora petroleum province. Paper presented at the Saint Petersburg Conference: Innovations in Geosciences.

Prischepa, O., Grokhotov, E., Makarova, I., Averyanova, O. \& Nikiforova, V. 2018c. Petroleum prospects of the domanik formation in timano-pechora province. Paper 
presented at the Saint Petersburg Conference: Innovations in Geosciences.

Prischepa, O.M. \& Averyanova, O.Y. 2017. Approaches to the hydrocarbon potential evaluation of the shale strata, domanik deposits of timan-pechora province. Paper presented at the EAGE/SPE Joint Workshop on Shale Science 2017: Prospecting and Development.

Prokhorova, M.P., Prodanova, N.A., Reznichenko, S.M., Vasiliev, V.P. \& Kireev, V.S. 2016. Innovation performance and its influence on enterprise economic efficiency in the market. International Journal of Economics and Financial Issues, 6, (Special Issue), 78-83.

Raupov, I. \& Podoprigora, D. 2017. Laboratory researches of the polymeric composition in the pore space of bulk models. International Journal of Applied Engineering Research, 12(3), 365-371.

Raupov, I.R. \& Korobov, G.Y. 2018. Research of polymer compositions rheological properties for oil production. Acta Technica CSAV (Ceskoslovensk Akademie Ved), 63(3), 493-500.

Sozinova, A.A., Okhrimenko, O.I., Goloshchapova, L.V., Kolpak, E.P., Golovanova, N.B. \& Tikhomirov, E.A. 2017. Industrial and innovation clusters: Development in Russia. International Journal of Applied Business and Economic Research, 15(11), 111-118.

Solnyshkina, M.I. \& Ismagilova, A.R. 2015. Linguistic landscape westernization and glocalization: The case of kazan, republic of tatarstan. XLinguae, 8(2), 36-53, doi:10.17846/XL.2015.08.02.36-53

Solnyshkina, M.I., Solovova, E.N., Harkova, E.V. \& Kiselnikov, A.S. 2016. Language assessment course: Structure, delivery and learning outcomes. International Journal of Environmental and Science Education, 11(6), 1223-1229, doi:10.12973/ijese.2016.392a.

Safieva, R.Z., Stavitskaya, A.V., Safieva, E.O. \& Aleksandrova, T.N. 2017. Hydrogenation of unsaturated hydrocarbons on pt and pd catalysts encapsulated in mesoporous bakelites. Chemistry and Technology of Fuels and Oils, 53(4), 455-463, doi:10.1007/s10553-017-0823-5.

Shagiakhmetov, A., Tananykhin, D., Terleev, A. 2018. Development of water-shutoff composition on the basis of carboxymethyl cellulose for fractured and fracturedporous oil and gas reservoirs. Acta Technica CSAV (Ceskoslovensk Akademie Ved) (ISSN: 00017043), 63 (3), 475-480.

Sharifov, A.R. \& Mardashov, D.V. 2018. Liquid solvent addition to steam for enhancing recovery of heavy oil with cyclic steam stimulation. Paper presented at the Saint Petersburg Conference: Innovations in Geosciences.

Sultanova, D. \& Mardashov, D. 2016. Research of the effect of scale inhibitors on the effectiveness of corrosion inhibitors in oil wells. International Journal of Applied Engineering Research, 11(18), 9460-9463.

Tananykhin, D., Tcvetkov, P., Kamoza, V. 2018. Analysis and Recommendations of Sand Consolidation Methods to Limit Sand Production in Gas Wells. Journal of Physics: Conf. Series, 1072, 012022, doi :10.1088/1742-6596/1072/1/012022.

Tananykhin, D., Saychenko, L. 2017. Sand control methods for the development of oil \& gas fields with hard to recover reserves. Espacios (ISSN: 07981015), 38(48), 31.

Tananykhin, D.S., Shagiakhmetov, A.M. 2016. Justification of technology and fluids for treatment of the unconsolidated carbonate reservoirs. International Journal of Applied Engineering Research (ISSN: 09734562), 11(1), 744-748.

Tarman, B. 2017. Editorial: The Future of Social Sciences. Research in Social Sciences and Technology, 2(2). Retrieved from http://ressat.org/index.php/ressat/article/view/329. 
Ushachev, I.G., Maslova, V.V., Chekalin, V.S. 2017. Economic problems of import substitution in the conditions of scientific and technological development of the agro-industrial complex of Russia. AIC: economics, management. №11, 4-11.

Ushachev, I.G., Maslova, V.V., Chekalin, V.S. 2018. State support of agriculture in Russia: problems, ways of their solution. AIC: economics, management. №3, 4-12.

Voronkova, O.Y., Akhmetshin, E.M., Sycheva, I.N., Shpakova, R.N., Pashkova, E.Y. \& Poltarykhin, A.L. 2018. Economic mechanism of regulating land relations in the agricultural sector of russia. European Research Studies Journal, 21(4), 280-291.

Vasiliev, B.U. \& Mardashov, D.V. 2017. Methods and tools for education and research in the information society. Paper presented at the Proceedings of the 2017 International Conference "Quality Management, Transport and Information Security, Information Technologies", IT and QM and IS 2017, 699-703, doi:10.1109/ITMQIS.2017.8085920.

Yamova, O.V., Maramygin, M.S., Sharova, I.V., Nesterenko, J.N., Sobina, N.V. 2018. Integral Valuation of an Enterprise's Competitiveness in the Industrial Economy. European Research Studies Journal, 21, (Special Issue 2), 777-787. 